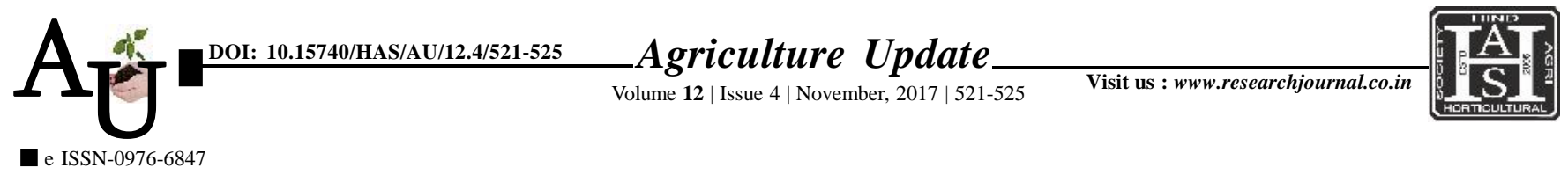

\title{
Research Article: Correlates of biodynamic compost method on its beneficiary farmers
}

\author{
口.T. KATOLE, UMESH R. CHINCHMALATPURE AND G.B. MORE
}

Article Chronicle : Received : 03.06.2017;

Revised : 15.08.2017; Accepted : 01.09.2017

KeY Words :

Correlates, Compost, Biodynamic

Author for correspondence :

\section{R.T. KATOLE}

Department of

Extension Education,

College of Horticulture

Dr. Panjabrao Deshmukh

Krishi Vidyapeeth;

Krishi Nagar, AKOLA

(M.S.) INDIA

Email:rkatole@

rediffmail.com

See end of the article for

authors' affiliations
SUMMARY : The present study was undertaken in 16 villages of Telhara Panchayat samiti of Akola district in Maharashtra state.For the present study, 112 beneficiary farmers were purposively selected from 16 villages and the data from selected 112 beneficiary farmers were collected. An exploratory research design was used for the present study. The findings of the present study revealed that majority of beneficiary farmers were from middle age group, had education upto high school level, belonging to small land holding, the annual income was observed above Rs.2,00,000/-, had medium level of animal possession (5-8 animal), had medium level of sources of information, had medium level of extension contact, had medium levels of scientific orientation, had medium levels of risk preference and innovativeness. The per cent change in annual income after use of biodynamic compost method was 11.76 per cent. Soybean and cotton crops showed change in average productivity in positive direction i.e. increase in productivity. Soybean showed maximum increase in average productivity $(16.71 \%)$ over base year followed by cotton $(10.76 \%)$. The variables viz., livestock possession, sources of information, scientific orientation, risk preference and innovativeness were found to be significant at 0.05 per cent level of probability with change in annual income, whereas independent variable extension contact had positive and highly significant relationship with change in productivity at 0.01 per cent level of probability. However, age and education had shown non-significant relationship with the change in annual income and change in productivity, respectively.

How to cite this article : Katole, R.T., Chinchmalatpure, Umesh R. and More, G.B. (2017). Correlates of biodynamic compost method on its beneficiary farmers. Agric. Update, 12(4): 521-525; DOI : 10.15740/HAS/ AU/12.4/521-525. 